\title{
Neoliberalism in geoeconomics: the case of Southeast Europe
}

\author{
Radenko Scekic \\ University of Montenegro \\ Montenegro \\ scekicr@yahoo.com \\ Mimo Draskovic \\ University of Montenegro \\ Montenegro \\ rookie@t-com.me \\ Milica Delibasic \\ International University of Travnik \\ Bosnia and Herzegovina \\ 23.mildel@gmail.com
}

Abstract. This paper analyzes theoretical and methodological grounds of geoeconomics as the extended arm of geopolitics and post-industrial development paradigm. The article selects its basic semantic components, terms and definitions, and explains the geoeconomic character of neoliberalism. The authors suggest a new term - the neoliberal geo-ideology. The influence of geoeconomics in the countries of South-East Europe (SEE) is demonstrated, and the destructive effects of neoliberalism, which serves as the official economic policy in SEE are discussed. The conclusion verifies the starting hypothesis noting the need for abandoning neoliberal economic policies in the SEE countries as such.

Received:

November, 2015 1st Revision: December, 2015

Accepted: January, 2016 $10.14254 / 2071-$ $8330.2016 / 9-1 / 5$

Keywords: geoeconomics, geopolitics, neoliberalism, institutions, Southeast Europe.

JEL classification: F02, P30.

\section{INTRODUCTION}

The end of last and the beginning of the current millennium was marked by the escalation of mutual relations of the great powers. Struggle for resources on the global level increased. Economic rivalries have become the dominant phenomenon. In this context neoliberal ideology ceded its place to geoeconomics. The latter explains geographical, economic, historical, political and institutional characteristics of a certain region. Jean K. and P. Savona (2007), B. Babic (2009), F. Kovačević (2010), A. Dugin (2007), D. Proroković (2011), J. Attali (2013) and others believe that for explanation of the current process of adjustment to new 
(global) economic and political demands it is necessary to be aware of recent geoeconomic phenomena and categories, because the current geopolitical rivalry of the great powers is happening on the field of economics and it is mostly the struggle for resources. Certanly, the noted rivalry will significantly correct the influence of global ecological problems.

Geoeconomics as well as the purpose and means of geopolitics in practice is present in all regions, including SEE. SEE region for centuries has represented the area in which were different civilization, political, economic, cultural, ethnic and religious interests have been clashing

The aim of this study is to critically and descriptively verify the influence of various modalities of geoeconomics and its neoliberal ideology in the SEE countries. Current crisis tendencies in the region overall and poor results of its transition are the outcomes of neoliberalism application. This assumes that all phenomena and categories under the umbrella of geoeconomics and neoliberalism acted simultaneously and synchronized, leading to combined, interactive and dominant influence on economic and political (in) stability of the SEE countries.

\section{THEORETICAL FRAMEWORK}

The SEE countries entered quarter of a century ago in a period of deep social transformation. Transition reforms (political, economic, institutional, legal, democratic, etc.) were closely linked and conditioned by current global trends. However is critically evaluated (positive or negative), globalization gradually builds up the general vectors of development. It is logical that the solutions of individual national problems are not possible without cooperation with the world-wide political, economic, cultural, institutional and other structures. In such situation, the implementation of national interests of each state is determined by the character of its access to resources, which are necessary for its development. Here is about resources in the widest sense: intellectual, financial, labor, energy, scientific, raw material, manufacturing and others.

Each new historical and development period requires changing (often paradigmatic) the way of thinking and behavior. It is came up, among other things, to the adaptation of civilized norms, achievements and contemporary challenges. More than two and a half decades, the changes take place extremely uneven through hybrid and heterogeneous processes of universalization of economic, technological, media, institutional, cultural and other flows. „Arrival of quite new civilization“ was indicated by A. Toffler (1980, p. 30). Stated changes were almost unfallibly predicted by I. Naisbit (1982).

They are the key base, promoters and supports of that universalization (its cause), but also conservationist of peripheral anachronism and poverty (its consequence). The above-mentioned flows and processes are in contrast, controversial and contradictory. They cover practically all aspects of life and society. In the literature they are also called cosmopolitanization, westernization and mondialisation, but mostly globalization, which is often uncritically identified with the post-industrial society (the term of D. Bell, 1973).

In the modern development phase of technological civilization, the world has entered into a wideformat model of so called post-industrial development (of society). Draskovic V. et al. (2010, p. 28) called it post-formation society and stated its basic manifestations:

- global interconnection of market economy, based on organizational (transnationalism, outsourcing, intercompany business, strategic alliances, clustering, diversification, etc.), and technological innovations (especially informatical, communicational and transport),

- forming of network management structure, production, distribution, global market and competition, through a virtual business interconnection, based on economic and legal flexibility,

- expansion of the movement of capital, goods, services and people, 
- exponential acceleration, overreaching and multiplication of changes (qualitative, quantitative, technological, institutional, organizational and etc.),

- the transition to the knowledge society and the so-called the "new economy", based on the rapid development of high information technologies, telecommunication networks and intellectual capital,

- separation of financial flows from the real sphere of production and trade ( "casino economy"), with a huge international movement of capital,

- rapid growth of service industry,

- strengthening and complexity of pluralistic institutional structure, with institutionalisation of world trade and international economic relations,

- economic liberalization and denationalization of goods and financial flows in the global market, according to the laws of big capital,

- liberal-democratic organizations of socio-political life, etc.

Geoeconomics and its geo-financial system of mentioned transborder manifestations and flows represent various forms of geo-economic expansionism. Its main objective is to promote the leading position and geo-economic interests. Geoeconomics has achieved its goals thanks to a colossal boom of innovation in all areas of social relations, especially in the domain of interdependent functioning of national and international institutions.

With the crisis of socialism on a global scale, the dominant influence of geopolitics is dissipated. The above-mentioned manifestations of globalization have enabled wider advent of geoeconomics. The postsocialist practices in SEE countries has shown that the impact of geo-economic factors has been synchronized with the acting of the various newly established national, corporate and alternative structures. They have, according to wealth and power, converted into superior "elite" that constrained economic choice and freedom of the most of individuals, even more than so much criticized the state. Although different in their character, their goals were by time and interest coresponded with the geo-economic goals.

\section{THEORETICAL AND METHODOLOGICAL BASICS OF GEOECONOMICS}

Bearing in mind the above mentioned, at the end of the 1980s the founder of the American school of geoeconomics E. Luttwak has formulated the idea that the geopolitical dominance of the United States should transformed into geoeconomic. The essence of his proposal was that it was necessary to elaborate and develop new technologies of domination. They should contribute to the formation of leadership status in the promotion of US interests in all parts of the world. At the same, the key idea was that mentioned promotion should be based on the global economic operations without the use of military force. By the opinion of Luttwak, rivalry between countries does not end with the completion of the strategic confrontation between the superpowers. It is increasingly transferred from the military-strategic sphere to the economy areas. Geopolitics is replaced by geoeconomics - a policy which is focused on winning and domination in the economic competition. Luttwack has defined the mission of geoeconomics as „the consolidation of economic threats". It has the task to develop methods of economic defense and performance, with the main objective "to provide the best possible employment for the most part of its population" (Luttwak, 1990), even if it is needed - to the detriment of the population of other countries.

Risk of geo-economic expansionism, which leads to the restructuring of economic borders and the subordination of state institutions by transnational structures has opened the problem of the protection of state interests. In addition, geo-economic expansionism relativises hypothetical model of civilizational develop- 
ment, which would allow achievement of benefits to all participants in the global process, as opposed to the geopolitical strategy, in which the victory of one means the defeat of another. Therefore, it seems that the geoeconomics is just the long arm of geopolitics, which blurs and beautifies mentioned victories and defeats.

Geoeconomics is the product of new knowledge, which appeared in the late 20th century with the germination of a concept of new universalism. V. Belousov and A. Lubsky (2013, p. 11) consider that new universalism is based on the theory of glocalization in postindustrial society. This is a new entity, which in various ways combines and adapts the global and local (V. Draskovic et al., 2010, p. 37). In this sense, geoeconomics based on the glocalization presents an innovation in designing global transformation of world system (order). It permeates all areas: production-technical, technological, institutional (functional and organizational) and so on. The key geo-economic trend is the creation of innovative environments through the internationalization of knowledge. Therefore, it is clear that there is an unbreakable unity between the geoeconomics and competitiveness in today's globalized world. In other words - one without the other is unthinkable.

Countries that are not cooperative in the geo-economic atlas of the world, are not aware of their economic interests and does not protect them. Therefore, they can not aspire to high world status, rating and appreciation. Of course, it must be borne in mind a fact that only highly competitive countries and their economic entities can be in a position to dictate the world ,agenda“, i.e. to provide exemplary models in the field of so-called „global economic growth“. It is understood that their ,innovative models“ enable filling the national budgets at the expense of redistribution of global incomes.

In all of this, most authors agree in assessment that geopolitics, geoeconomics and geoculture represent the three distinct but closely related discourses. Using the mentioned discourses can be described the functioning of the modern world and modeled contemporary struggle for resources. This struggle ultimately means - the struggle for survival.

Geoeconomics is a term that characterizes a new branch of knowledge that studies the concrete reality. It is an area of interaction between sets of different sizes and characters in terms of control over economic resources, regardless of the fact that this control exceeds the limits of the territorial political boundaries (powers). While some authors (eg. Tsymbursky, 2003) include geoeconomics in geopolitics, the other (Wallerstein, 2004; Chase-Dunn, 1991) in the field of „hegemonic spheres“ of geoeconomic functioning of the world systems, the third (Luttwack, 1990, Kochetov, 2010) try to declare geopolitics outdated and replace it with geoeconomics. Nevertheless, we believe that the geoeconomics is the autonomous area, as it includes everything relating to the control of ekonomskimh resources in the framework of the existing structures of territorial authorities. It analyzes the impact of various economic, demographic and ecological factors that are closely related to the spatial position of a countries or regions, their natural resources and climatic conditions.

Geoeconomics is a new interpretation of the world through:

- the system of economic indicators,

- interweaving of national economies and transnational economic and state structures,

- involvement of the national economies in the internationalized chains of goods and services production.

The globalization expands and deepens the process of geoeconomics, transforming the world into unique, integral, „closer“ ( „shorter") space. The basic characteristic of this new "geo-economic space” is formation of technological unity of the world.

Geoeconomic dynamics includes the laws of market development (Collins, 1999, p. 172), accumulations, concentration of capitals between countries, relocation of business centers, replacement of exchange mechanisms, redistribution of world incomes, material and financial resources, changes in the global status of individual countries and so on. Its object of study includes the development processes of national and 
regional entities, but also the real international structures (economic, financial and integration associations), transnational corporations, the various economic regions, free economic zones and geopolitical entities (blocks). In this sense, geo-economic dynamics discusses categories of economic growth and development, foreign trade, international investments, external debt, economic dependency, etc. Geoeconomicaly conducted foreign policy includes a strategy for conquering other market space, but also for the geoeconomic defense of the state (Prorokovic, 2014).

The closest to us is the opinion of Jean K. (1996), who believes that the geoeconomics is naturally evolved from a geopolitical elaboration ( "geopolitical culture“ - Wallerstein, 1991), and it is not an alternative to geopolitics, but represents its integral (organic) part, which has special methodology. It uses a geopolitical logic in a special version: as „logic of flow“ of resources, particularly financial. Thanks to computerization and globalization of the world economy, all social and economic processes are taking place much faster. For the consequences now no one cares: from disparities between the rich and all others (the poor and the middle class), through enormous debt, to environmental disasters and threats.

\subsection{Neoliberal „geo-ideology“}

Today, it is not disputed that the geoeconomics is unavoidable during studying of international relations, as it was considered by E. Luttwak (1990, p. 17). Lorot P. (1999, p. 15) also noticed about „the comprehensiveness of the term geoeconomics and its truly planetary dimension". However, for our topic it is important that Luttwak noticed its influence in the era of globalization through the dominance of neo-liberal ideology. This is exactly diferencia specifica of contemporary competition among countries.

Starting from the significant role of the neo-liberal ideology in global relations, especially in some postsocialist countries (SEE, etc.), we consider that in the context of geoeconomics action can be formulated new compound - geoideology. It represents a strong connective tissue between geopolitics and geoeconomics, i.e. the preparatory phase and the foundation for the acting of geoeconomics.

The ideology is the social process. It acts through certain areas (church, family, education, political parties, syndicates, media). Let us remember that L. Althusser (1970) distinguished the state repressive apparatus (police, judiciary, army, state administration) and the state ideological apparatus, which is invisible and holds society together. He pointed out their interdependence.

The neoliberal model of "development" is based on the individualist ideology and a new system of values, which allowed unlimited expression of personal interests, and thus a rapid enrichment and making power (social, political, party and economic). The neo-liberal ideology in reality has separated from its scientific and philosophical heritage. It has become a tool in the hands of so-called "new elite" (class of non-market enriched individuals), big capital and business. Therefore Baletic Z. (2005) calls it "ideological dogmatism", which has become a form of economic behavior, which leads to the radical reorganization of society in favor of small and privileged social groups. The problem is that neoliberal ideology ignores class differences in society, social issues and exploitation, giving primacy to extreme individualism.

Like any other, the neoliberal ideology simplifies and reduces reality, in order to its simple demagoguery and apologetics were acceptable and understandable for the masses. V. Drašković (2014, p.) says that the neoliberal ideology is politicaly imposed and contain the imperial discourse, because it is turned into dogmatization, totalitarianism and subjectivism (the justification of realization individuals interests). It ignores the moral, human, social and ecological consequences of economic decisions. At the same time, barren rhetoric (apologetics) connects ideological indoctrination and interest orientation, and individualism (of the privileged) became the foundation of formal institutional monism as theoretic and ideological basis of economic neoliberalism. 
V. Drašković (Ibid.) characterizes neoliberalism by prefix quasi. He considers that the degeneration of the theoretical model of neoliberalism led to a new form of neo-liberal imperialism, who inherited colonial (geographically) and the neo-colonial (industrial). In essence of neoliberalism are exploitation, financial dependence, technological and organizational domination, forms of total control, imperialist motives and privileged interests. In mentioned context may be searched for geo-economic fundamentals of neoliberalism as a specific "geoideology“, because it substitutes human values by profit based on "global ideology without morality" (Mesarić, 2012). At the same background are the interpretations about the connection of neoliberalism with "geopolitics of chaos and empire of liberalism" (Ramonet, 1997, p. 37), with the "third world religion" of the 20th century (Wertheim, 1997, p. 22) and with „ideological discourse that legitimize the strategy of imperialist capital" (Amin, 1997, p. 34).

\section{THE INFLUENCE OF GEOECONOMICS AND NEOLIBERALISM IN SEE COUNTRIES}

SEE region (Balkans) has always been a convenient ground for conflict of interest of the great powers. This is the territory in which they clashed for centuries, but also in which permeated the different cultures and civilizations, religions and zones of influence of external factors (political, economic, military, institutional, religious, etc.). In geo-economic terms, the struggle to ensure control over the world's reserves of energy is the most important factor influencing the global events over the last 100 years (Engdahl, 2011, p. 13). Due to the crisis of the gas transport from Russia via Ukraine to the EU, there was a necessity for the construction of alternative routes. In order to enhance the geopolitical impact to the SEE countries, Russia has planned to install over their territory pipelines for the transport of natural gas („South“ and „Turkish“ stream). Thus, the SEE region has found in geo-economic focus. Russian military intervention in Crimea and disorder of political relations with Turkey stopped the mentioned geo-economic plans. Therefore, the SEE countries has deprived of significant economic benefits.

Investing abroad is also an important form of geo-economic impacts. As for the SEE region, many countries have exercised significant geo-economic impact over foreign investments in the transition period. There was especially active influence of Russian investments in Montenegro and Serbia. But, considering that the mentioned investments were flowing into various forms of consumption, we believe that a large portion of them turned into disinvestments.

As the third form of geoeconomic influence we can single out neoliberal ideology, which has been paradigmatic in the countries of SEE from 1990. It was institutionalized through introduction the official neoliberal economic politics. In addition to its social destructiveness in terms of reduction of the proclaimed principles of the reform, it has produced also the devastating effects in the economy (V. Drašković et al., 2010). International and national monopolies were by neoliberal methods choking competition and economic freedom. They were by non-market ways making strong positions and competencies. All this was partly similar to the understanding of Oxelheim L. (1996) that "the neoliberal model assumes externalization of unfavorable operations, own costs, the crisis, the difficulties and problems". Therefore, in the people was created a paradoxical, but unfortunately accurate impression that in the practical application neoliberalism virtually renounced its „liberality” by which for decades sweared.

Manifestation of „reform“ forms in the transition conditions have adapted by the global geo-economic recipes, which Shomsky N. (1999, pp. 5-20) called the „ideology of the rich..., fundamental political paradigm..., which serves for dominance". The doctrine of economic neoliberalism was undoubtedly the ideological foundation of two historical parallel processes - globalization and the post-communist transition. At the 
same the "reform results“ of neoliberalism in SEE countries were enabled by fiasco of two basic economic institutions: state regulation and market regulation. They were counterproductive in terms of development all over the transition period because they abused by nomenclature of the authorities and their lobbyists. Therefore was appeared the need for a apologetic affirmation of so-called „micro-state“.

Vulgarized use of neo-liberal economic policy throughout the transition period has blocked the economic and social development. Crude, uncritical, unselective and radical (by „shock therapy") have been used various methods of polarization, scramble privatization, principles of double standards, the implementation of unequal exchange, a number of unevenness and disproportions, collapse of economic infrastructure and above all - an institutional vacuum. In a word, there have ruled specific forms of violence, understood in the definition of D. North, J. Wallis, and B. Weingast (2009).

After decades of historical distance, it can be concluded that the practical application of neoliberal recipes held in post-socialist conditions of inadequate microeconomic environment and undeveloped institutional environment. Let us remember that Berkowitz et al. (2003, pp. 165-195) pointed to the phenomenon of „inappropriate“ imported institutions ( $\mathrm{bad} f \mathrm{ft}$ ), concrete local conditions and specifics.

Table 1

The conditional model of neoliberalism acting in SEE countries

\begin{tabular}{|c|}
\hline Geo-economic vulgarization of theoretical neo-liberal model \\
\hline \\
\hline Imports ( ,transplant”) of inadequate microeconomic and macroeconomic recipes \\
\hline \\
\hline Programmed, instrumented and orchestrated apologetics (interest type) \\
\hline$\downarrow$ \\
\hline Practical anti-development realization of narrow interests group of ,elite” over alternative institutions \\
\hline $\boldsymbol{~ T h e ~ i n c r e a s e ~ i n ~ o p p o r t u n i s t i c ~ b e h a v i o r ~}$ \\
\hline$\downarrow$ \\
\hline Poor economic and social outcomes (the crisis), with the rapid and huge growth of foreign debt
\end{tabular}

Source: author's creations.

Deficit of pluralistic and effective institutions was and remained the main braking factor of development. In conditions of the institutions deficit, quasi-neo-liberal values (monistic type: the market, individualism) have in theoretical level substituted by reactive rhetoric about reforms, and in the practical level by all forms of non-state monopolies and alternative institutions. They created a specific and improvised type of business activity, which Drašković V. (2010a, p. 9) called „concealer economy“, which is dominated by dictatorship of the newly created riches and so-called „elite“.

In terms of boundless neoliberal dynamics of deregulation have broken the real limitations of economic reality, degenerated moral and institutional pillars of development, as well as the motives of rational human behavior. Application of quasi-institutional violence (political and economic), that Kulić S. (2000, p. 867) called „neo-Darwinism“, led in the observed countries to new forms of dictatorship, domination, alienation, enormous social differences, apathy of the population, high unemployment, poverty and debt, the collapse of the economy and the like. All this created conditions that resemble on some new form of so-called ,imperial culture". It consists of elitism, interests greed, a specific concept of power which tends to turn into a total 
domination (of the parties in power, the leaders and privileged individuals). This raises the question of the moral dimensions of the current crisis, which is best reflected in the contradiction between the extravagance of developed and survival of undeveloped, or via a drastic increase of the gap between rich and poor.

Since the opinion of O. Williamson (2000, p. 605), the political and economic ruling structures are always responsible for development of economic institutionalization, it is clear that in that level should be look for the main culprit for the transition failures of SEE countries. Deficit of market regulation and its misuse caused strengthen of alternative institutions and opportunistic behavior (which usually had sociopathological character). Through alternative social engineering reproduced the institutional vacuum and strengthened the power of newly created "elite" (the alleged „efficient owners").

Table 2

The essence of the geo-economic acting of neoliberalism

\begin{tabular}{|c|c|c|}
\hline Process & & Result \\
\hline $\begin{array}{c}\text { vulgarization of theoretical models and apologetic } \\
\text { rhetoric }\end{array}$ & $\rightarrow$ & unjust order of government \\
\hline$\downarrow$ & & $\downarrow$ \\
\hline dogma of the market, individalism, mini country & & institutional monism \\
\hline$\downarrow$ & & $\downarrow$ \\
\hline interests motivation and ideology & $\rightarrow$ & affirmation of the power concept and totalitarianism \\
\hline$\square$ & & $\downarrow$ \\
\hline global regulation and national deregulation & $\rightarrow$ & transnational neo-imperialism \\
\hline
\end{tabular}

Source: author's creations.

In Table 2 we have tried in a selective and hypothetical way to model the essence of geo-economic acting of neoliberalism. In doing so, we started from the belief that neoliberalism represented a new form of economic determinism. Process manifestation of geoeconomic action over neoliberalistic methodology has its gradualist and concrete results, which are aimed at establishing a new world order ruled by neo-imperialist relations of dependence (polycentric type) - among several centers of power and huge resource periphery.

Many paradoxes in the SEE countries, which have happened on relations theory-practice, mass-individualism and pluralism-monism led to the conversion of traditional and civilizational values in quasineo-liberal values. In that process, geoeconomy has through neoliberal methods subordinated to its goals politics, culture, history, knowledge, institutions, morals and interests of the people.

\section{CONCLUSION}

According to all available indicators, the current activity of geoeconomic approach was focused on new forms of domination of the major powers and regions. They are operationally and functionally focused on a specific area of institutional domination, which guarantees economic success, security, business and minimize various types of risk (political, social and other). This is one of the causes of poor and slow adaptation of the underdeveloped countries to the changing conditions on the world market.

In addition to institutional domination, geoeconomics used two groups of special methods. One is related to the effects of high technologies and second to methods of economic wars (non-tariff barriers, control of technology, financial, information and cyber wars, etc). 
The great impact of the global struggle for resources in combination with various (following) global economic turmoils, migration crisis, currency and hybrid wars, migration crisis, ruined economies represent a reality in SEE.

In order to verify the proposed hypotheses, it is proved that the geopolitical conflicts and economic sanctions, combined with the economic crisis and neoliberal dogma was part of an expansive geo-economic politics, which have an extremely negative impact on the social and economic reality in SEE. In addition, it has been shown that the external destructive influences have distinct geo-economic character and that the SEE countries became victims of geo-economic conflicts of the great powers.

The complexity of the geo-economic reality is constantly increasing, as well as the risks of a new recession. It is a fact that implies the abandonment of the current official neoliberal economic policy, which proved to be not only unsuccessful, but disastrous for the economy and people of the SEE. Constantly declining of industrial production in the overall GDP cannot be compensated by the development of the service sector. The increase in unemployment, foreign trade deficit, foreign debt and other bad economic indicators require immediate creation of consistent economic policy. This is the only true way to adapt and overcome the growing geo-economic problems.

\section{REFERENCES}

Althusser, L. (1970), Lenin and Philosophy and Other Essays, Ideology and Ideological State Apparatuses // http://www. marxists.org/reference/archive/althusser/1970/ideology.htm, referred 28.09.2015)

Amin, S. (1997), „Capitalisme, impérialisme, mondialisation”, Recherches internationales, No. 48, 33-47.

Attali, J. (2014), Geopolitika ponižavanja, L'Express, Paris // http://blogs.lexpress.fr/attali (referred on 29/12/2015)

Babic, B. (2009), Geoekonomija - stvarnost i nauka, Megarend revija, Vol. 6, No. 1, pp. 27-54.

Bell. D. (1973), The Coming of Post-Industrial Society: A Venture in Social Forecasting, New York: Basic Books.

Baletić, Z. (2005), Ekonomski liberalizam i ekonomska znanost, Radovi HAZU, No. 43, pp. 1-45 (In Croatian).

Belousov, V. M., Lubsky, A.V. (2013), Geoeconomic Paradigm of Scientific Research, Terra Economicius, Vol. 11, No. 4, pp. 10-17.

Berkowitz, D. et al. (2003), „Economic Development, Legality and the Transplant Ef-fect“, European Economic Review, Vol. 47, No. 1, pp. 165-195.

Chase - Dunn, Ch. K. (1991), Global Formation: Structures of the World Economy, London, Oxford and New York: Basil Blackwell.

Chomsky, N. (1999), Profit Over People: Neoliberalism \& Global Order, Seven Stories Press, New York-London.

Collins, R. (1999), Macrohistory: Essays in Sociology of the Long Run, Stanford: Stanford University Press.

Draškovic, V. et al. (2010), Globalizacija u ogledalu razvoja, krize i medija, Podgorica: Elit (In Sebian).

Draskovic, V. (2010a), "The Real Institutionalization as a Condition of the Efficient Economic Politics and Economic Development", Montenegrin Journal of Economics, Vol. 7, No. 1, 5-20.

Draskovic, V. (2014), Neoliberal metaphor as a quasi-economic paradigm in function of vulgarized institutional monism and an experiment of interest, SPH: Celje, Osijek, Czestochowa, Kotor.

Dugin, A. (2007), Geopolitika postmoderna - vremena novih imperij. Očerki geopolitiki 21. veka, Sankt-Peterburg: Amfora.

Engdahl, W. (2011), A Century of War: Anglo-American Oil politics, Wiesbaden: edition Engdahl.

Kochetov E.G. (2010), Geoeconomics. Exploration of the world economic space: Textbook for universities, Moscow: Norma (In Russian)

Kovačević, F. (2014), Teoretičari klasične geoplitike, Podgorica: CGO (In Serbian). 
Kulić, S. (2000), „Koncepcija neoliberalizma, edukacija i egzistencija“, Ekonomski pregled, Vol. 51, No. 9-10, 867-894 (In Serbian).

Lorot, P. (1999), Introduction á la Géoéconomie, Paris: Economica.

Luttwak, E. (1990), From Geopolitics to Geoeconomics: Logic of Conflict: Grammar of Commerce, The National Interest, No. 20, pp. 12-34.

Jean, C. (1996), Geopolitica, Bari: Laterza.

Jean, M., Savona, P. (1997), Geoeconomics, economic domination, and of space, Moskow: Ad Marginem (In Russian).

Mesaric, M. (2012), „Neoliberalism vs. Planning as a Institute of Socio-Economic Development“, Montenegrin Journal of Economics, Vol 8, No. 3, pp. 19-25.

Naisbitt, I. (1982), Megatrends: Ten New Directions Transforming Our Lives, New York: Warner Books.

North, D.C., Walis, J.J., and Weingast, B.R. (2009), Violence and Social Orders - A Conceptual Framework for Interpreting Recorded Human History, The Syndicate of the Pres of the Cambridge University.

Oxelheim, L. (1996), Financial Markets in Transition - Globalisation, Investment and Economic Growth, London: Routledge and International Thomson Press.

Prorokovic, D. (2014), Geoekonomski položaj Balkana i strateški cevovodi // http://www.ceopom-istina.rs/ (referred on 26/12/2015) - In Serbian.

Ramonet, I. (1997), Géopolitique du Chaos, Paris: Galilée.

Toffler, A. (1980), The Third Wave, New York: William Morrow Company.

Tsymbursky, V. (2003), Russian and geoeconomics, Pro et contra, Vol. 8, No. 2, pp. 178-216. (In Russian).

Wallerstein, I. (1991), Geopolitics and Geoculture, Cambridge: Cambridge University Press.

Wallerstein, I (2004), World-Systems Analysis: An Introduction, Durham, NC: Duke University Press.

Wertheim, F. (1997), Third World: Whence and Whither? Protective State versus Agressive Marcet, Amsterdam:Het Spinhius.

Žan, K., Savona, P. (2007), Vivodi: geoekonomika kak instrument geopolitiki // http://www.archipelag.ru/geoeconomics (referred on 23/12/2015) - In Russian 